УДК 334.012:658.15

Яремко І. Й.,

i.yaremko@i.ua, ORCID:0000-0003-3556-0609,

д. е. н., проф., професор кафедри обліку та аналізу, Національний університет “Львівська політехніка", м. Львів

\title{
ЕКОНОМІЧНИЙ ІНСТРУМЕНТАРІЙ В УПРАВЛІННІ ФІНАНСОВО-ЕКОНОМІЧНОЮ СТІЙКІСТЮ СУЧАСНИХ ТОРГОВЕЛЬНИХ ПІДПРИЕМСТВ
}

\begin{abstract}
Анотація. У статті обтрунтовано критерій фінансово-економічної стійкості базовим індикатором в управлінні сучасними торговельними підприємствами. Метою даного дослідження є формулювання концептуальної спрямованості адаптації економічного інструментарію управління фінансово-економічною стійкістю торговельних підприємств. Встановлено, що в кризових економічних умовах критерій фінансово-економічної стійкості для будь-якого торговельного підприємства стає не тільки основою забезпечення стабільної діяльності і головною передумовою його перспективного розвитку, але й орієнтиром можливостей здійснювати свою діяльність взагалі. Розкрито систему інструментальних засобів механізму управління стійкістю торговельного підприємства та їх основні функиії. Доведено, шо удосконалення чи адаптація управлінського інструментарію створює можливості подолання торговельним підприємством ризиків $і$ загроз, які перешкоджають його сталому розвитку в довгостроковій перспективі. Аргументовано необхідність адаптації існуючого економічного інструментарію для забезпечення ефективності проиесів управління стійкістю підприємств торговельної галузі в умовах кризового суспільно-економічного середовища. Сформульовано окремі аспекти вдосконалення економічного інструментарію в прочесах забезпечення стійкої діяльності торговельного підприємства. Зокрема встановлено, що для адаптаиії функиіонально орієнтованої системи управління стійкістю торговельного підприємства необхідний суттєво удосконалений набір економічного інструментарію. Для забезпечення ефективності процесів управління стійкістю підприємств торговельної галузі в умовах кризового суспільно-економічного середовища у иъьому інструментарію необхідно додатково враховувати такі важливі фактори як створення резервів для захисту основного капіталу, реальність витрат $i$ доходів майбутніх періодів, а також реальна вартість економічних ресурсів $і$ капіталу.
\end{abstract}

Ключові слова: торговельне підприємство, фінансово-економічна стійкість, управління, економічний інструментарій.

Yaremko I. Y., i.yaremko@i.ua,ORCID:0000-0003-3556-0609,

Doctor of Economics, Professor, Professor of the Department of Accounting and Analysis, "Lviv Polytechnic" National University, Lviv

\section{ECONOMIC TOOLS IN MANAGING THE FINANCIAL AND ECONOMIC SUSTAINABILITY OF MODERN TRADE ENTERPRISES}

\begin{abstract}
The article substantiates the criterion of financial and economic sustainability as a basic indicator in the management of modern trade enterprises. The purpose of this study is to formulate the conceptual orientation of the adaptation of economic tools for managing the financial and economic sustainability of trade enterprises. It is determined that in crisis economic conditions the criterion of financial and economic for any trade enterprise becomes not only a basis for maintenance of stable activity and the main precondition for its perspective development, but also a landmark of opportunities to carry out the activity in general. The system of tools of the mechanism of the trading enterprise sustainability management and their basic functions is revealed. It is proved that the improvement or adaptation of managerial tools creates opportunities for the trade enterprise to overcome the risks and threats that hinder its sustainable development in the long run. The necessity of adaptation of the existing economic tools for ensuring the efficiency of the processes of trade enterprises sustainability management in the conditions of crisis socio-economic environment is argued. Some aspects of improvement of economic tools in the processes of ensuring sustainable operation of a trade enterprise are formulated. In particular, it is determined that for adaptation a functionally oriented sustainability management system of a trade enterprise a significantly improved set of economic tools is needed. To ensure the effectiveness of the sustainability management of the trade enterprises in a crisis socio-economic environment in these tools it is necessary to consider additionally such important factors as the creation of reserves to protect fixed capital, the reality of future costs and revenues as well as the real cost of economic resources and capital.
\end{abstract}

Key words: trade enterprise, financial and economic sustainability, management, economic tools.

JEL Classification: D21, D81, L81, M29

DOI: https://doi.org/10.36477/2522-1205-2020-61-02 


\section{Herald of Lviv University of Trade and Economics. Economic Sciences. № 61, 2020}

Постановка проблеми. Мінливість ринкової системи господарювання щораз обумовлює потреби зміни форм та методів управління суб'єктами господарювання будь-якої сфери економіки. Ці зміни відбуваються під впливом як домінування найбільш значимих на певний період функціональних напрямків менеджменту, так і визнання в загальноекономічному просторі ключового індикатора ефективного управління (зростання інвестиційної привабливості, інтегрального показника конкурентоспроможності, прибутковості капіталу тощо). Стагнація і рецесія загальноекономічного середовища та соціально-політична невизначеність планетарного масштабу спричинили появу значної кількості загроз для стабільного і результативного функціонування переважної більшості економічних систем. У цих умовах критерій фінансовоекономічної стійкості для будь-якого сучасного підприємства стає не тільки основою забезпечення стабільної діяльності і головною передумовою його перспективного розвитку, але й орієнтиром можливостей здійснювати свою діяльність взагалі.

Наведене обгрунтовує теоретико-прикладну позицію про те, що фінансово-економічну стійкість торговельного, як і будь-якого іншого, підприємства слід розглядати ключовим індикатором управління сучасним підприємством. Ця універсальна категорія характеризує захищеність економічної системи передусім від негативних впливів зовнішнього середовища. В цьому синтезованому індикаторі відображається також спроможність підприємства швидко усунути різноманітні внутрішні фактори, що позначаються на його діяльності, або пристосуватися до існуючих умов. Практика управління підприємством торговельної галузі у вкрай несприятливому зовнішньому середовищі надає додаткової актуальності “дослідженню теоретико-методологічних та організаційнометодичних питань забезпечення системи управління фінансовою стійкістю торговельного підприємства" [1, с. 53].

Пошук нових шляхів забезпечення стійкого функціонування підприємств торговельної галузі насамперед пов'язується із з'ясуванням реального стану фінансово-економічної стійкості у поточний момент. У сучасних швидко змінюваних умовах соціально-економічного середовища керівний орган торговельних підприємств повинен у будь-який момент мати об'єктивну інформацію, яка характеризує поточний рівень фінансово-економічної стійкості підприємства. Достовірність такої інформаційної бази є запорукою для побудови адекватної для реальних економічних умов системи управління стабільним функціонуванням торговельного підприємства в короткостроковій перспективі. Така цільова інформація формулює також функціональну переорієнтованість економічного інструментарію для управління капіталом (складом, структурою). Дослідження ролі стійкості підприємства в умовах фінансово-економічної кризи показують, що “важливим питанням також $є$ збалансування структури капіталу підприємства відповідно до стадії його розвитку задля забезпечення його економічної ефективності” [2, с. 24].
Удосконалення чи адаптація управлінського інструментарію створює можливості подолання торговельним підприємством ризиків і загроз, які перешкоджають його сталому розвитку в довгостроковій перспективі. Зміна функціональної орієнтації управлінського інструментарію та адаптація всієї системи управління на критерій фінансово-економічної стійкості вимагають проведення низки організаційних заходів для створення адекватної концепції управління. Практична гострота досліджуваної проблематики та ії не розробленість у практичній площині обгрунтовують актуальність теоретичних досліджень за цим напрямком.

Аналіз останніх досліджень і публікацій. Проблемами забезпечення системи управління фінансово-економічною стійкістю підприємства різних галузей економіки, в т.ч. торговельної, займалися багато українських науковців. В останніх тематичних дослідженнях насамперед наголошується на потребі практичної переорієнтації сформульованих і визнаних в минулому управлінських концепцій, у яких домінують ключові індикатори зростання вартості капіталу, його рентабельності тощо. Вплив світової пандемії на глобальне суспільно-економічне середовище вніс суттєві корективи в поглядах на потенціал майбутнього функціонування і розвитку підприємств торговельної галузі. Серед багатьох проблемних напрямків актуальною для сучасної економіки визнається тематика "проведення поглиблених науковометодичних і прикладних досліджень, присвячених економічній стійкості й розробці сучасних методів та інструментів в напрямі забезпечення високої адаптивності підприємств до умов внутрішнього і зовнішнього середовища" [3, с. 74]. У цьому контексті Є. І. Масленніков обгрунтовано доводить, що “в умовах суттєвих змін економічного простору проблема управління фінансовою стійкістю торговельного підприємства набуває пріоритетний характер, вирішення якої вимагає вдосконалення існуючого механізму управління" [1, с. 53].

За результатами тематичного дослідження Л. М. Докієнко відзначає “потребу підприємств торгівлі в удосконаленні управління фінансовогосподарською діяльністю на основі їх фінансової стійкості" та робить висновок, що “на вітчизняних підприємствах управління фінансовою стійкістю не підкріплені відповідними теоретичними дослідженнями та модельним інструментарієм процесу управління нею” [4]. Загалом у сфері теоретичних досліджень та аналітичних оглядів функціонування підприємств торговельної галузі визнається потреба теоретично-наукового обгрунтування шляхів i напрямків удосконалення існуючих чи розроблення нових, адекватних реальним умовам, механізмів забезпечення ї стабільного фінансово-економічного стану. При цьому обгрунтовано доведено, шо проблематика організації і впровадження на торговельних підприємствах дієвої на практиці цільової (функціонально-орієнтованої) системи управління стійкістю стала найбільш важливою складовою управлінських процесів. 
Постановка завдання. Метою даного дослідження є формулювання концептуальної спрямованості адаптації економічного інструментарію управління фінансово-економічною стійкістю торговельних підприємств.

Виклад основного матеріалу дослідження. Трансформаційні процеси в зовнішньому економічному середовищі та пониження соціальносуспільного життєвого рівня завжди супроводжуються надмірними ризиками та загрозами для торговельних підприємств. Вони викликають потребу пошуку якісно нових шляхів забезпечення стабільної діяльності. Зазвичай це взаємопов'язується зі сформованим у минулих і поточному періодах потенціалом фінансово-економічної стійкості. Відповідно до постулатів економіки процеси управління фінансово-економічною стійкістю розглядаються як невід'ємна складова управління торговельним підприємством у цілому. У виокремленому вигляді цю управлінську підсистему розглядають через сукупність процесів, спрямованих на протидію внутрішнім і зовнішнім факторам. У більш конкретизованому змісті фінансово-економічну стійкість будь-якого підприємства пов'язують із його перспективною платоспроможністю, тобто критерієм забезпечення фінансових можливостей підприємства на оглядову перспективу: “процесний підхід до управління економічною стійкістю передбачає розроблення й реалізацію управлінських рішень стратегічного та оперативного характеру, які забезпечують стабільне функціонування i розвиток підприємства" [3, с. 75].

Реально оцінюючи сучасний стан і передумови функціонування торговельних підприємств в оглядовій перспективі, можна обгрунтовано стверджувати, що базовою умовою їх стійкого функціонування $\epsilon$ забезпечення фінансовоекономічної стійкості. Тому розробка акцентованого на цей критерій управлінського інструментарію розглядається засобом можливостей i здатностей функціонування торговельних підприємств взагалі. Зарубіжні і вітчизняні аналітичні огляди наводять низку фактів про припинення діяльності численних торговельних підприємств, які в попередні періоди не змогли забезпечити належний рівень потенціалу своєї фінансово-економічної стійкості. Очевидним $€$ i той факт, що синтезований показник (інтегральний індикатор) про стан поточної фінансовоекономічної стійкості $є$ основою формування стратегії та встановлення можливостей і тенденцій розвитку підприємства. Тому на теперішній час визначений у той чи інший спосіб його слід розглядати одним із найважливіших критеріїв для інвесторів та контрагентів ринкових відносин.

Фінансово-економічна стійкість зазнає впливу багатьох чинників, які за своєю вагомістю порізному впливають на стійкість підприємства. Стабільне функціонування будь-якої господарської системи забезпечується в управлінських процесах операційної діяльності із застосуванням налагоджених і відповідних до умов зовнішнього середовища і специфіки діяльності підприємства функцій менеджменту. Адаптивна управлінська система за допомогою адекватних для таких цілей економічних механізмів та інструментів повинна посилити або послабити силу дії зовнішніх чи внутрішніх факторів впливу.

У теоретичних дослідженнях i на практиці розглядають функціональний, ситуаційний, системний і процесний підходи до управління фінансово-економічною стійкістю економічних систем. У кожному 3 підходів передбачається створення організаційно-економічних умов для забезпечення ефективності операційної діяльності підприємства. Критерії ефективності, а разом з ними і об'єкти та завдання процесів управління в кризових умовах $\epsilon$ надмірно складними і різноманітними. Виходячи 3 такої диспозиції, найбільш прийнятними можна вважати ситуаційний та функціональний підходи до управління фінансово-економічною стійкістю сучасних торговельних підприємств. У прийнятій парадигмі ситуаційного управління економічною стійкістю управлінські рішення приймають за ознаками виявлених проблем (фактичними чи визначеними незворотними у короткостроковій перспективі). За такого підходу виникає потреба делегування управлінських функцій нижчим рівням (організаційним структурам підприємства) для швидкої реакції на змінювані умови (адаптивність управлінської вертикалі, особливо у великих мережевих торговельних підприємствах).

Базові засади функціонального підходу дають змогу за сформульованими у ньому принципами створювати адекватні для реальної практики функціональні види менеджменту (організацію процесів управління фінансово-економічною стійкістю на основі взаємопов'язаних управлінських функцій). Концептуальний базис цього підходу в управлінні фінансово-економічною стійкістю аргументується доцільним тим, що “використання тільки загальних функцій управління є недостатнім, оскільки економічно стійким визначають таке підприємство, функціонування структурних елементів якого також дозволяє відновлювати його ресурсний потенціал та зберігати рівноважний стан за допомогою змін та адаптації відповідно до нових умов господарювання" [5]. Поряд 3 наведеним відзначимо і те, що “превентивна форма гарантування фінансової стійкості $\epsilon$ найбільш ефективною в антикризовому регулюванні та управлінні й потребує використання системного підходу, який охоплює в собі систему планування поточної діяльності, реагування на фактори зовнішнього та внутрішнього середовища, виявлення основних ризиків поточної діяльності та забезпечення неперервності господарської діяльності” [6, с. 25].

У будь-якій із парадигм функціонально орієнтований економічний інструментарій управління фінансово-економічною стійкістю $\epsilon$ складовою фінансового механізму і його доцільно розглядати через “систему форм, методів та інструментів, які застосовуються у фінансовій діяльності для забезпечення функціонування всіх сфер та напрямків, шляхом оперування фінансовими ресурсами 3 урахуванням економічних інтересів торговельного підприємства" [1]. Незалежно від управлінської 
парадигми фінансово-економічна стійкість розглядається категорією, що забезпечує певні умови стабільного функціонування підприємства (рис. 1).

Формулювання адекватних процесів управління насамперед пов'язується 3 формалізацією об’єкта управління. У теорії і на практиці традиційно розглядають чотири типи фінансовоекономічної стійкості (абсолютна, нормальна, нестійкий та кризовий стан). Цю економічну категорію переважно встановлюють на основі більш формалізованих індикаторів фінансової стійкості та фінансового стану підприємства, зокрема шляхом внесення до цих показників деяких коригувальних індикаторів. Обчислення наведених перших двох, достатньо формалізованих за методикою економічних категорій, здійснюються на основі певної кількості обраних коефіцієнтів та їх дослідження в динаміці. При цьому використовують різні підходи (методики) визначення фінансової чи економічної стійкості - коефіцієнтний, агрегатний, балансовий, інтегральний, маржинальний, факторний, бальний тощо. Переважно їх зводять до одного інтегрованого показника, який складається 3 декількох найбільш вагомих для підприємства коефіцієнтів. Визначення певних меж значення синтезованого критерію $€$ найбільш поширеним у вітчизняній практиці для ідентифікації ефективності на практиці системи управління стійкістю підприємства. На основі результатів оцінного та аналітичного інструментарію визначають потребу, характер i спрямованість адаптації такої функціонально орієнтованої підсистеми управління до змін середовища функціонування підприємства (рис. 2).

Дієвість впровадженої у практику адаптивної системи управління фінансово-економічною стійкістю залежить від правильного добору/композиції економічного інструментарію, визначеної для кожного інструментального засобу функціональної ролі та сформованого на цій основі загального механізму. Визначений і впроваджений у практичну діяльність управлінський інструментарій повинен забезпечувати якісний оперативний моніторинг змін у рівні фінансово-економічної стійкості, аналіз основних проблем негативного впливу, оцінку можливостей підприємства та сформулювати заходи для забезпечення досяжного рівня стійкості. В узагальненому вигляді під цим поняттям розуміють, що “основною складовою частиною фінансової стабільності $€$ потенційна стійкість підприємства щодо нарощування обсягів діяльності й забезпечення фінансової рівноваги" [7, c. 61].

У більш конкретизованому розкритті стійкого стану йдеться про стабілізацію грошових потоків, зростання вартості капіталу (бізнесу), забезпечення ліквідності активів, максимізацію дисконтованого доходу, стабільний рівень прибутковості. Наведені та деякі інші індикатори стійкого стану підприємства знаходять вираз у так званій структурній ліквідності балансу. В основу управлінських рішень щодо стабілізації фінансово-економічної стійкості все ж слід покладати результати аналізу фінансового стану підприємства. Саме деталізована оцінка економічних ресурсів і капіталу, встановлення їх продуктивної сили в реальних економічних умовах дозволяють об'єктивно визначити тактику і стратегію управління стійкістю. У поточному моменті це стосується забезпечення економічно обгрунтованого (оптимального) товарного обігу, що є базовою основою стабільної діяльності підприємств торговельної галузі. Для переважної більшості вітчизняних торговельних підприємств виникають проблеми із наявністю власного (основного) та оборотного капіталу, достатній рівень якого є основною умовою забезпечення прийнятного для цих підприємств рівня фінансово-економічної стійкості.

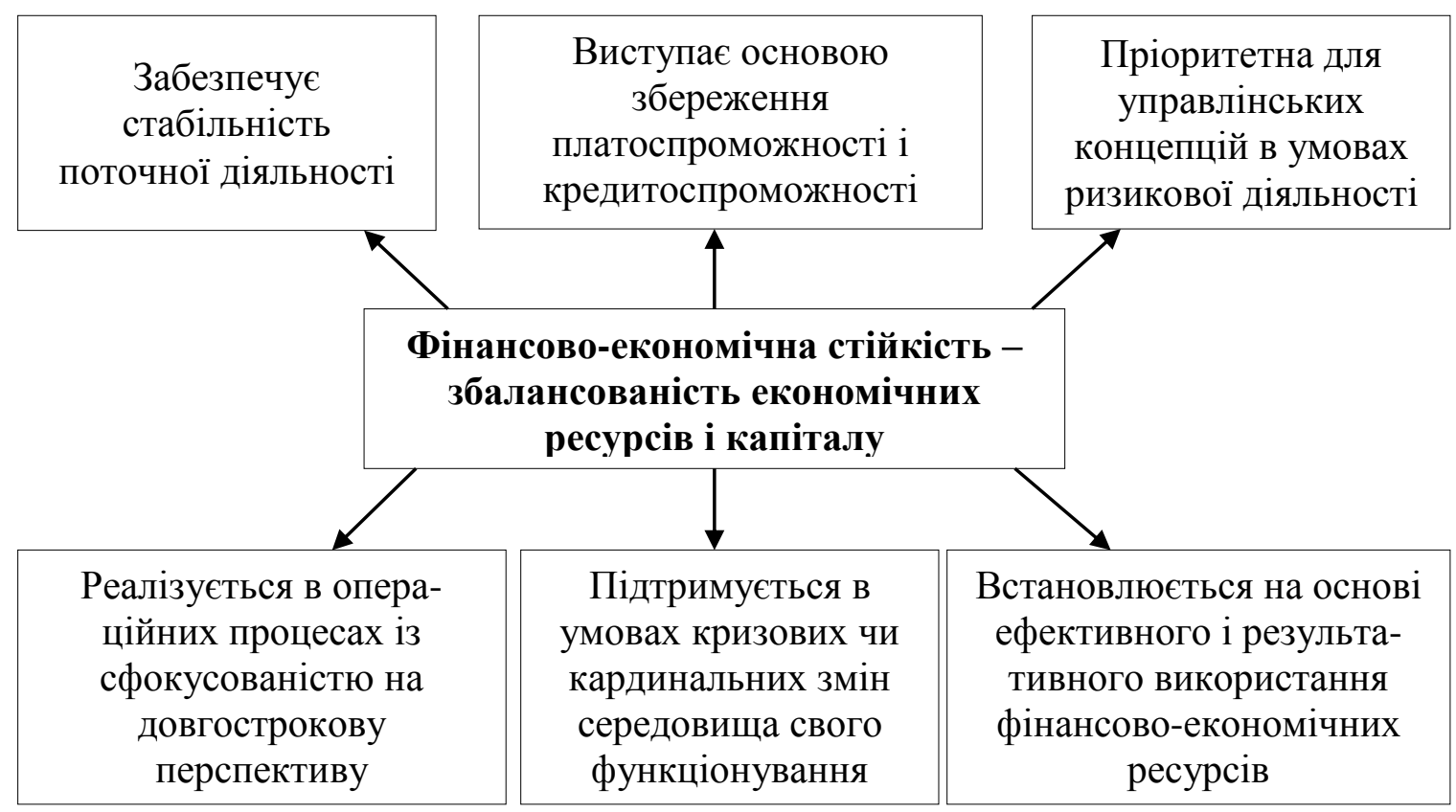

Рис. 1. Функція і роль фінансово-економічної стійкості в процесах управління підприсмством 


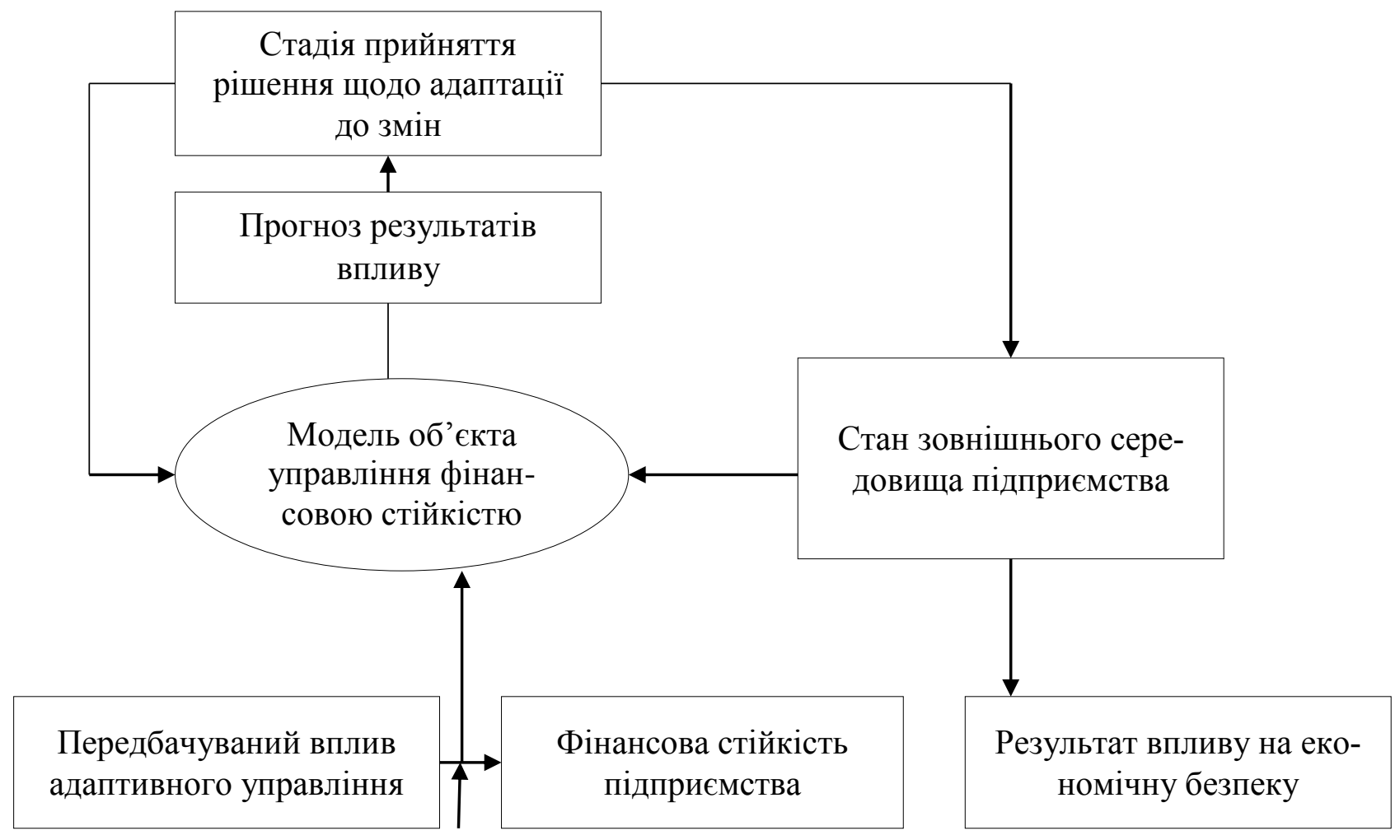

Рис. 2. Схема комплексного управління фінансовою стійкістю підприємства [7]

Враховуючи швидко змінювані умови у зовнішньому середовищі, найбільш відповідним економічним інструментом слід вважати експресдіагностику, проведення якої стосовно “фінансового забезпечення розвитку торговельних підприємств передбачає, в першу чергу, визначення стану фінансового забезпечення досліджуваних підприємств 3 одночасним встановленням оптимального значення інтегрального показника, що дозволить проводити порівняння отриманих фактичних значень і встановлювати висновки, «діагноз» щодо стану досліджуваних об'єктів" [8, c. 205]. Фінансово-економічний аналіз як управлінський інструмент $є$ базовим для цільової підсистеми управління фінансово-економічною стійкістю підприємства. Модульна структура такого типу аналізу зорієнтована на опрацювання звітних і бухгалтерських даних. В аналітичних процесах застосовуються прийоми детермінованого і стохастичного факторного аналізу причин змін і рівня фінансово-економічної стійкості підприємства.

Процедурна сторона такого типу аналізу достатньо відома, як і безпосередньо технологічний процес оцінки фінансової чи скоригованої на фінансову економічність стійкості підприємства. Основний етап аналітичних процедур акцентований на розрахунку системи кількісних і деяких якісних показників, які за певним підходом їх поєднання розкривають комплексну характеристику і оцінні судження про рівень фінансово-економічної стійкості підприємства. При цьому відзначимо, що в аналітичні процедури вводиться базова інформація (звітно-бухгалтерські дані), грунтована на історичних (минулих) оцінках економічних ресурсів i капіталу. В умовах більш-менш стабільного економічного середовища результати такого аналізу можуть задовольняти процеси формування управлінських рішень. Проте в кризових ситуаціях результати аналізу суттєво викривлюють інформацію про стан і зміни фінансово-економічної стійкості підприємства.

Адаптивність інструментарію аналізу фінансово-економічної стійкості можна вбачати у введенні до його складу моніторингу інформаційної бази, тобто процедур відслідковування кон'юнктурних змін у вартості активів та капіталу. Інструменти моніторингу слід розглядати допоміжним засобом у системі аналітичних процедур, традиційно грунтованих на бухгалтерському вартісному виразі. Аналітичні огляди діяльності відомих торговельних комплексів дають підстави до висновку, що в умовах сучасної економіки до складу аналізу слід вводити процедури оцінки витрат і доходів майбутніх періодів i, особливо, стану резервування основного капіталу підприємства.

Висновки i перспективи подальших досліджень у даному напрямі. Критерій фінансовоекономічної стійкості слід об'єктивно розглядати базовим індикатором в управлінні сучасними торговельними підприємствами. Для адаптації функціонально орієнтованої системи управління стійкістю торговельного підприємства необхідний суттєво удосконалений набір економічного інструментарію. Для забезпечення ефективності процесів управління стійкістю підприємств торговельної галузі в умовах кризового суспільно-економічного середовища у цьому інструментарію необхідно додатково ураховувати такі важливі фактори як 


\section{Herald of Lviv University of Trade and Economics. Economic Sciences. № 61, 2020}

створення резервів для захисту основного капіталу, реальність витрат і доходів майбутніх періодів, а також реальна вартість економічних ресурсів і капіталу.

\section{ЛIТЕРАТУРА}

1. Масленніков Є. І. Методологічні та практичні засади дослідження системи управління фінансовою стійкістю торговельного підприємства : монографія / Є. І. Масленніков. - Одеса : Прес-кур'єр, 2015. - $316 \mathrm{c}$.

2. Заячківська О. В. Роль фінансової стійкості підприємства в умовах фінансово-економічної кризи / Заячківська О. В., Яскал Я. А. // Вісник НУГВП. Серія "Економічні науки”. - 2018. Вип. 2(82). - С. 21-26.

3. Рудич О. О. Сутність економічної стійкості підприємств та процесу їі забезпечення / Рудич О. О., Герасименко I. О., Ткаченко К. В. // Інноваційна економіка. - 11-12’2016. - С. 74-78.

4. Докієнко Л. Д. Управління фінансовою стійкістю підприємств торгівлі : автореф. дис. ... к.е.н.: спец. 08.07.05 - економіка торгівлі та послуг. Київський національний торговельно-економічний університет, 2005.

5. Григорська Н. М. Управління економічною стійкістю підприємства в розрізі наукових надбань та сучасних підходів / Н. М. Григорська // Економічний вісник НТУУ «КПІ» : збірник наукових праць. - 2012. - № 9. - С. 241-247.

6. Гринкевич С. С. Економічні основи стратегічного управління фінансовою стійкістю підприємства в умовах ринкових перетворень / С. С. Гринкевич // Науковий вісник НЛТУ України : зб. наук.техн. праць. - Львів : РВВ НЛТУ України. - 2012. Вип. 18.5. - С. 110-114.

7. Ареф'єва О. В. Адаптивне управління фінансовою стійкістю підприємства при забезпеченні його економічної безпеки / О.В.Ареф'єва, С. Т. Пілецька, Н. М. Кравчук // Проблеми системного підходу в економіці. - 2020. - Вип. 1(1). C. 80-89 [Електронний ресурс]. - Режим доступу: http://nbuv.gov.ua/UJRN/PSPE_print_2020_1(1)_14.

8. Стрішенець О. Аналітичний огляд фінансової стійкості підприємства / О. Стрішенець // Економічний часопис Східноєвропейського національного університету імені Лесі Українки. - 2018. № 3. - С. 58-65 [Електронний ресурс]. - Режим доступу: http://nbuv.gov.ua/UJRN/ echcenu_2018_3_10.

9. Барна М. Ю. Діагностика фінансового забезпечення розвитку роздрібних торговельних підприємств / Барна М. Ю., Стефанишин О. Б. // Науковий журнал "Причорноморські економічні студії". 2016. - Вип. 12-1. - С. 204-209.

\section{REFERENCES}

1. Maslennikov, Ye. I. (2015), Metodolohichni ta praktychni zasady doslidzhennia systemy upravlinnia finansovoiu stijkistiu torhovel'noho pidpryiemstva : monohrafiia, Pres-kur'ier, Odesa, 316 s.

2. Zaiachkivs'ka, O. V. and Yaskal, Ya. A. (2018), Rol' finansovoi stijkosti pidpryiemstva v umovakh finansovo-ekonomichnoi kryzy, Visnyk NUHVP. Seriia "Ekonomichni nauky", vyp. 2(82), s. 21-26.

3. Rudych, O. O. Herasymenko, I. O. and Tkachenko, K. V. (2016), Sutnist' ekonomichnoi stijkosti pidpryiemstv ta protsesu ii zabezpechennia, Innovatsijna ekonomika, 11-12', s. 74-78.

4. Dokiienko, L. D. (2005), Upravlinnia finansovoiu stijkistiu pidpryiemstv torhivli : avtoref. dys. ... k.e.n.: spets. 08.07.05 - ekonomika torhivli ta posluh. - Kyivs'kyj natsional'nyj torhovel'noekonomichnyj universytet,.

5. Hryhors'ka, N. M. (2012), Upravlinnia ekonomichnoiu stijkistiu pidpryiemstva v rozrizi naukovykh nadban' ta suchasnykh pidkhodiv, Ekonomichnyj visnyk NTUU «KPI» : zbirnyk naukovykh prats', № 9, s. 241-247.

6. Hrynkevych, S. S. (2012), Ekonomichni osnovy stratehichnoho upravlinnia finansovoiu stijkistiu pidpryiemstva v umovakh rynkovykh peretvoren', Naukovyj visnyk NLTU Ukrainy : zb. nauk.-tekhn. prats', RVV NLTU Ukrainy, L'viv, vyp. 18.5, s. 110114.

7. Aref'ieva, O. V. Pilets'ka, S. T. and Kravchuk, N. M. (2020), Adaptyvne upravlinnia finansovoiu stijkistiu pidpryiemstva pry zabezpechenni joho ekonomichnoi bezpeky, Problemy systemnoho pidkhodu v ekonomitsi, vyp. 1(1), s. 80-89, available at: http://nbuv.gov.ua/UJRN/PSPE_print_2020_1(1)_14.

8. Strishenets' O. (2018), Analitychnyj ohliad finansovoi stijkosti pidpryiemstva, Ekonomichnyj chasopys Skhidnoievropejs'koho natsional'noho universytetu imeni Lesi Ukrainky, № 3, s. 58-65, available at: http://nbuv.gov.ua/UJRN/echcenu_2018_3_10.

9. Barna, M. Yu. and Stefanyshyn, O. B. (2016), Diahnostyka finansovoho zabezpechennia rozvytku rozdribnykh torhovel'nykh pidpryiemstv, Naukovyj zhurnal "Prychornomors'ki ekonomichni studii", vyp. 12-1, s. 204-209.

Стаття надійшла до редакиії 12 жовтня $2020 p$. 